\title{
User Centered Design Method for Developing a Mobile-Based Product Distribution Application
}

\author{
Meriska Defriani $^{1)^{*}}$, Mochzen Gito Resmi ${ }^{2) *}$, Okta Amien Permana ${ }^{3)}$ \\ ${ }^{1) 2) 3)}$ STT Wastukancana, Indonesia \\ ${ }^{1)}$ meriska@stt-wastukancana.ac.id, ${ }^{2)}$ mochzen@stt-wastukancana.ac.id, ${ }^{3)}$ aminntulvevo@gmail.com
}

Submitted : Nov 17, 2021 | Accepted : Dec 12, 2021 | Published : Jan 3, 2022

\begin{abstract}
Anyelir Cake And Bakery is the largest cake shop in Purwakarta which is engaged in the production of various kinds of cakes. In the process of distributing products from the central store to branch stores, they still use WhatsApp to place orders. This causes frequent discrepancies in the number of products requested and the number of products received due to an error in reading the message. In this study, a mobile-based application will be built that is able to manage order data more accurately. The development of this application uses the User Centered Design (UCD). This is a design method that focuses on user needs so that the final result of this application does not need to change user behavior when using the application. The UCD method consists of four stages, namely plan the human centered design, specify user and organizational requirements, product design solutions, and evaluate design against user requirements. In the development process, application testing was carried out to get feedback from users with good scores, namely an average of 4 (agree) and 5 (strongly agree). This shows that the application is in accordance with the needs of the user.
\end{abstract}

Keywords: mobile-based; User Centered Design; user-oriented

\section{INTRODUCTION}

Increasement number of smartphone users in Indonesia has led to the emergence of many mobile-based applications. The application which installed directly on the smartphone is able to facilitate human work, especially those that require high mobility. The positive impact of its use can also be felt in various fields, one of which is in business field.

Anyelir Cake and Bakery Purwakarta is one of the largest cake shops in Purwakarta Regency which sells several cake products such as birthday cakes and brownies. Anyelir Cake and Bakery Purwakarta has five branch stores and one production house. Every day the central store will send cake products to the branch store according to the branch store's request. The branch store records cake products that are still available and orders cakes that are sold out. Cakes ordered will be sent to the branch store the next day by the central store. Currently, product orders from the central store which will then be distributed to branch stores are still being done through the WhatsApp application. Orders are made by the cashier by writing a list of product names and quantities. This system has been running for about four years. The problem that arises with this system is that there is often a mismatch between the number of products ordered and the number of products received. This is due to employee errors in reading messages in the WhatsApp application. In this case, the branch store will receive the wrong number of products. This can reduce sales because the availability of products that are in high demand by consumers is lacking or there are products with excess stock that ultimately do not sell. This impact certainly affects store revenue and cash flow. Therefore, a mobile-based application was built that is able to manage product order data more accurately.

In developing an application, a development method is needed. One of the development methods that can be used is User Centered Design (UCD). This is a design method that focuses on user needs so that the final result of this application does not need to change user behavior when using the application. Previously, the UCD method was used by Adnan, et al., to develop mobile-based e-learning in Jember University. UCD method considered to be able to increase user comfort in using the application (Adnan et al., 2018). In addition, Krisnoanto, etc. also uses UCD method to build an Android-Based e-Learning application. Based on the results of the questionnaire, the application built with the UCD approach has a good average feasibility with a score *name of corresponding author

This is an Creative Commons License This work is licensed under a 


\begin{tabular}{|l|l|r|}
\hline Sin 11010 & $\begin{array}{l}\text { Sinkron : Jurnal dan Penelitian Teknik Informatika } \\
\text { Volume 7, Number 1, January 2022 } \\
\text { DOI : https://doi.org/ 10.33395/sinkron.v7i1.11218 }\end{array}$ & $\begin{array}{r}\text { e-ISSN : 2541-2019 } \\
\text { p-ISSN : 2541-044X }\end{array}$ \\
\hline
\end{tabular}

above $80 \%$ and an average success rate with a score above 90\% (Krisnoanto et al., 2018). UCD method also used to develop android-based mobile commerce in Lamandau Store. The results of the alpha and beta testing showed that the android-based mobile commerce application on the lamandau store showed that the interface that was built was very good and in accordance with user needs (Vani et al., 2021).

\section{METHOD}

This research use User Centered Design (UCD) as the method. UCD is a method of user-centered interface design concept by drawing conclusions from user experience through efficient observation (Silvia Francesca Maria Pizzoli et al., 2019). The interface design process focuses more on usability goals, user characteristics, tasks, and workflows in interface design (Intan Sandra Yatana Saputri et al., 2017). All information obtained through a survey about analysis of habits. The results of the analysis then processed to obtain a user friendly interface design decision (Garret, 2011). The developer can see from a more specific user point of view (Untoro, 2020). Meanwhile, according to Adnan, et al., UCD is a method that refers to the approach to the wishes of the user. With the application of this method, users will feel comfortable when interacting with the system so that the information provided can be conveyed properly (Adnan et al., 2018). Rubin and Chisnell state that there are three principles of UCD. First, Focus on users and tasks. Identify and categorize users which will then be in direct contact between users and the design team. Interaction is done in a systematic, structured approach to collect information about users. Second, evaluation of product usage measurement. Emphasis is placed on measuring learning behavior and user ease very early in the design process, through developing and testing prototypes with real users. Third, repeated design and testing. Iterative design allows for a complete reconstruction and rethinking of the design, through testing of models or design concepts. Iterative design allows one to shape a product through the process of design, testing, redesign, and retesting activities (Rubin \& Chisnell, 2008).

There are four processes in UCD (Frobenius, 2021)(Iqbal et al., 2020), namely plan the human centered process, specify the context of use from the user and organization, product design solution, and evaluate design against user requirement (Albani \& Lombardi, 2010). These processes can be seen in Figure 1.

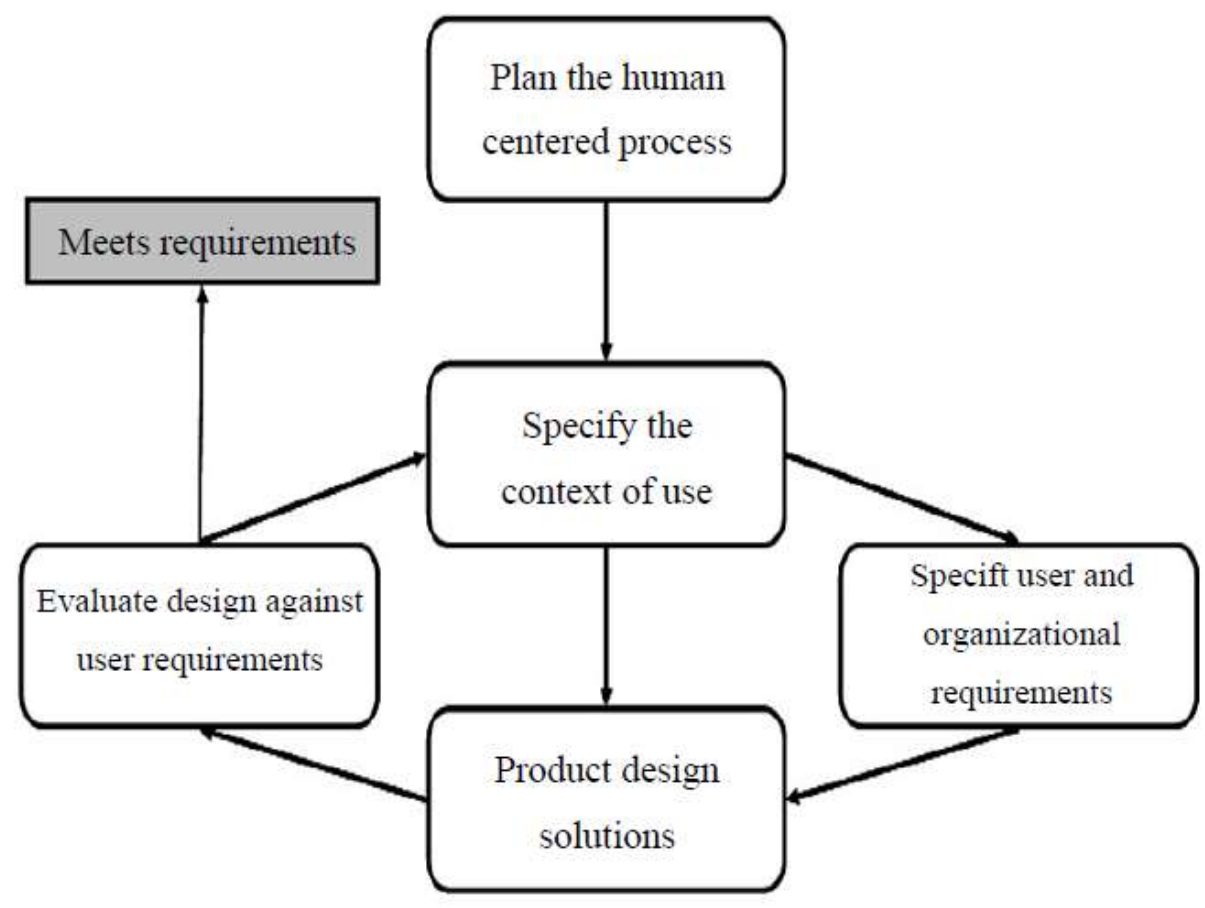

Figure 1. User Centered Design Processes

The explanation of each stage of the UCD software development method is as follows:

1. Plan the Human Centered Design

At this stage, a study of basic theoretical literature that supports the research is carried out to gather the needs for research. Literature studies are carried out by reading and understanding reference books, journals, and other media related to data processing in general that support and reinforce existing theories, so as to instill a commitment that the design UCD can fulfill user wishes.

*name of corresponding author

This is an Creative Commons License This work is licensed under a

Creative Commons Attribution-NonCommercial 4.0 International

License. 


\section{Specify the Context of Use}

At this stage, the needs analysis stage is carried out to find out what kind of users can be used as respondents to conduct analysis.

3. Specify User \& Organization Requirements

At this stage, identification of the details of user needs is carried out to collect information on the needs related to system design.

4. Product Design Solutions

After going through several previous stages, at this stage the system design is carried out by making a proposed system in the form of a flow map, Unified Modeling Language (UML), and interface design.

5. Evaluate Design Against User Requirements

The evaluation stage is the last stage in making an application using the User Centered Design (UCD) method. At this stage, the user can provide feedback on the application used which the results will later be used as reference material for application makers in improving applications. This stage is evaluating the entire system that has been adapted to user needs. This evaluation is carried out to determine the extent to which the resulting design is in accordance with user needs using a questionnaire technique. The questionnaire uses Likert scale as the benchmark value. Likert scale is a scale used to measure perceptions, attitudes or opinions of a person or group regarding an event or social phenomenon. There are two forms of questions on the Likert scale, namely the form of positive questions to measure the positive scale, and the form of negative questions to measure the negative scale. Positive questions were scored 5, 4, 3, 2, and 1; while the negative questions were given a score of $1,2,3,4$, and 5 (Pranatawijaya et al., 2019). At the final stage of UCD, applications are evaluated using a questionnaire. The answers to the questionnaire were measured using a Likert scale and using a calculation equation which can be seen in equation (1).

$$
r=\frac{k}{j} \times 100 \%
$$

Where the value of $\mathrm{r}$ is the result, $\mathrm{k}$ is the total respondents in each answer, and $\mathrm{j}$ is the total respondents overall (Priyatna, 2019).

\section{RESULT}

The results of this research will be explained in stages according to the phases in the UCD process. Here is the explanation:

\section{Plan the Human Centered Design}

The basic theories used in this study are the theory of UCD by Garret (2011) and previous research on the application of UCD for the development of mobile-based systems by Priyatna (2019).

\section{Specify the Context of Use}

At this stage, interviews were conducted with six respondents, namely one head of the central Anyelir shop and five employees with positions as cashiers. The cashier at each branch store acts as a product ordered from the branch store to the central store. The things that were explored in the interview were how the process of ordering products from branch stores to central stores was currently running, as well as what obstacles often occurred. In addition to interviews, direct observations were also made at the central store regarding how the product ordering system from branch stores to the center and the current delivery process were carried out.

\section{Specify User and Organization Requirement}

Based on the results of interviews and observations, an application is needed that can process product order data more accurately. The features needed in the application are as follows:

1. Application logins according to access rights

2. Input, edit, and delete orders by employees at branch stores

3. Confirm orders entered by the central store admin

4. Managing product data by the central store admin

5. Presenting order report

\section{Product Design Solution}

The applications that are built consist of two types, namely applications for administrator and users. The application design is described using UML which consists of use cases, activities, sequences, and class diagrams. The design of the application interface for user can be seen in Figure 2 and for administrator can be seen in Figure 3.

*name of corresponding author 


\section{Evaluate Design Against User Requirement}

Evaluation is done by using a questionnaire on one administrator and 14 cashiers who will use the application. The results of design testing for admin needs can be seen in Table 1, while the results of design testing for user needs can be seen in Table 2 .
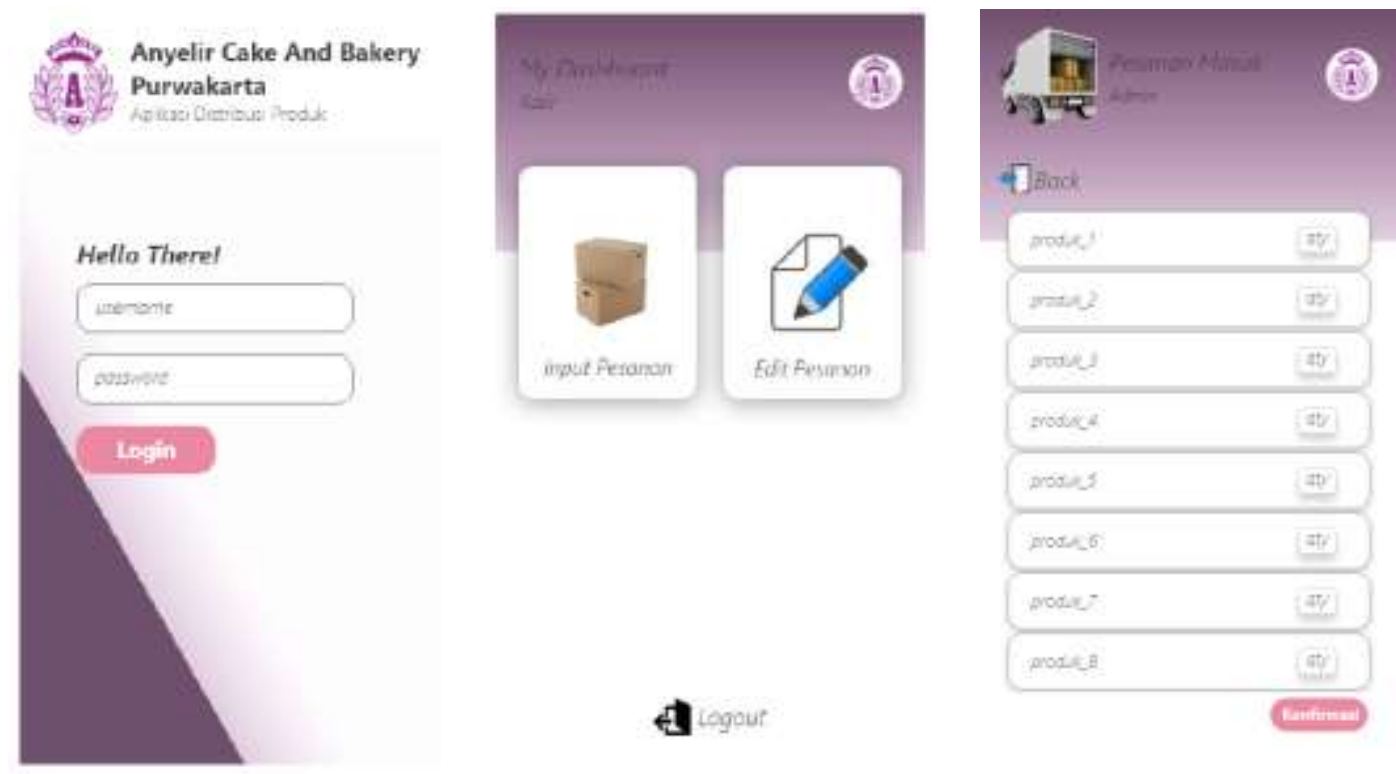

Figure 2. Application Interface Design for User
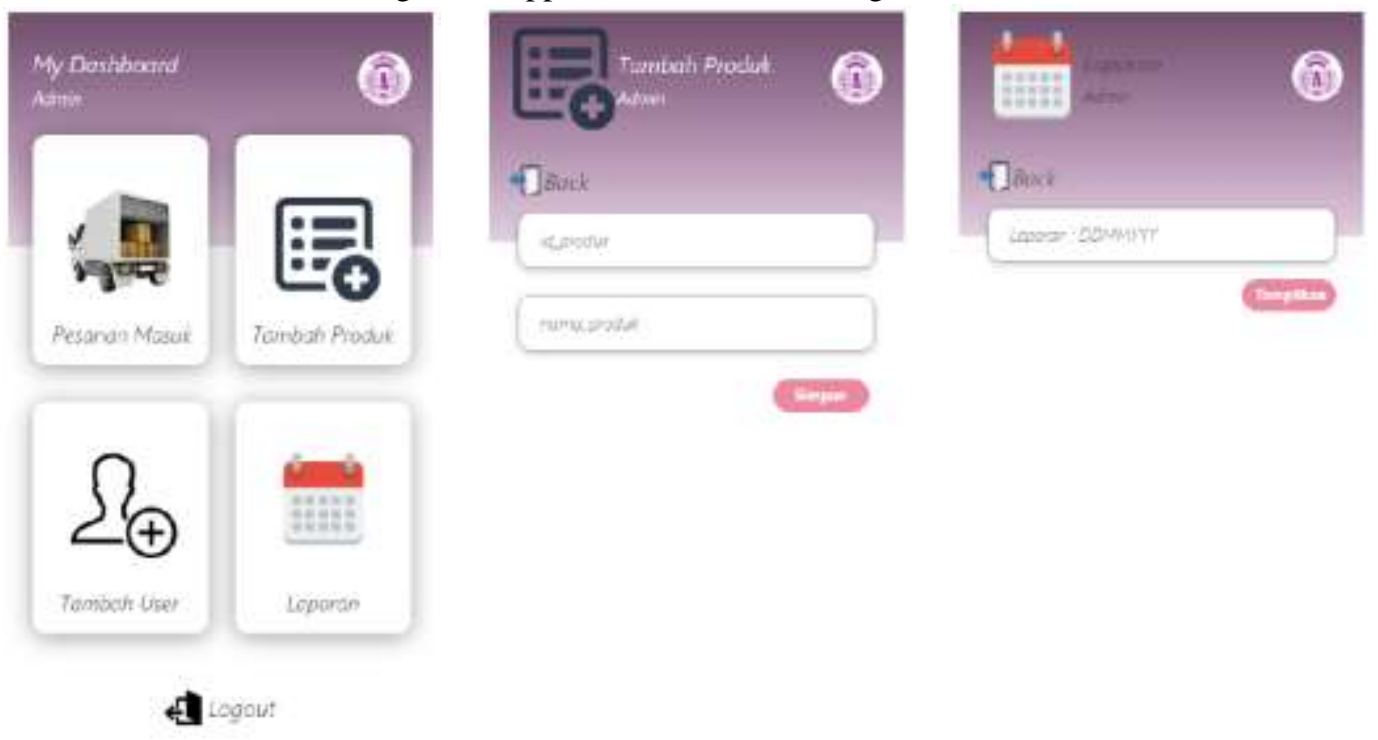

Figure 3. Application Interface Design for Administrator

Table 1. Evaluate Design Against User Requirements Administrator

\begin{tabular}{|c|l|c|c|c|c|c|}
\hline \multirow{2}{*}{ Number } & \multicolumn{2}{|c|}{ Question } & \multicolumn{4}{c|}{ Result } \\
\cline { 3 - 7 } & & $\begin{array}{l}\text { Strongly } \\
\text { Agree }\end{array}$ & Agree & Undecided & Disagree & $\begin{array}{c}\text { Strongly } \\
\text { Disagree }\end{array}$ \\
\hline 1 & $\begin{array}{l}\text { Does the function to view incoming } \\
\text { orders in the application meet the needs? }\end{array}$ & $100 \%$ & $0 \%$ & $0 \%$ & $0 \%$ & $0 \%$ \\
\hline 2 & $\begin{array}{l}\text { Does the function of adding new products } \\
\text { in the application meet the needs? }\end{array}$ & $100 \%$ & $0 \%$ & $0 \%$ & $0 \%$ & $0 \%$ \\
\hline 3 & $\begin{array}{l}\text { Does the function of adding new users to } \\
\text { the application meet the needs? }\end{array}$ & $100 \%$ & $0 \%$ & $0 \%$ & $0 \%$ & $0 \%$ \\
\hline 4 & Does the function of viewing order & $0 \%$ & $100 \%$ & $0 \%$ & $0 \%$ & $0 \%$ \\
\hline
\end{tabular}

*name of corresponding author

This is an Creative Commons License This work is licensed under a

Creative Commons Attribution-NonCommercial 4.0 International

License. 


\begin{tabular}{|l|l|r|}
\hline Gin 110101 & $\begin{array}{l}\text { Sinkron : Jurnal dan Penelitian Teknik Informatika } \\
\text { Volume 7, Number 1, January 2022 }\end{array}$ & e-ISSN : 2541-2019 \\
DOI : https://doi.org/ 10.33395/sinkron.v7i1.11218 & p-ISSN : 2541-044X \\
\hline
\end{tabular}

\begin{tabular}{|c|l|c|c|c|c|c|}
\hline \multirow{2}{*}{ Number } & \multicolumn{2}{|c|}{ Question } & \multicolumn{3}{|c|}{ Result } \\
\cline { 3 - 6 } & & $\begin{array}{c}\text { Strongly } \\
\text { Agree }\end{array}$ & Agree & Undecided & Disagree & $\begin{array}{c}\text { Strongly } \\
\text { Disagree }\end{array}$ \\
\hline & reports in the application meet the needs? & & & & & \\
\hline 5 & $\begin{array}{l}\text { Is the interface in the product distribution } \\
\text { application easy to understand? }\end{array}$ & $100 \%$ & $0 \%$ & $0 \%$ & $0 \%$ & $0 \%$ \\
\hline
\end{tabular}

Table 2. Evaluate Design Against User Requirements User

\begin{tabular}{|c|c|c|c|c|c|c|}
\hline \multirow[b]{2}{*}{ Number } & \multirow[b]{2}{*}{ Question } & \multicolumn{5}{|c|}{ Result } \\
\hline & & $\begin{array}{c}\text { Strongly } \\
\text { Agree }\end{array}$ & Agree & Undecided & Disagree & $\begin{array}{l}\text { Strongly } \\
\text { Disagree }\end{array}$ \\
\hline 1 & $\begin{array}{l}\text { Does the function to order product in this } \\
\text { application meet the needs? }\end{array}$ & $71.4 \%$ & $28.6 \%$ & $0 \%$ & $0 \%$ & $100 \%$ \\
\hline 2 & $\begin{array}{l}\text { Does the function of editing products in } \\
\text { this application meet the needs? }\end{array}$ & $64.3 \%$ & $35.7 \%$ & $0 \%$ & $0 \%$ & $100 \%$ \\
\hline 3 & $\begin{array}{l}\text { Does the function of removing product in } \\
\text { this application meet the needs? }\end{array}$ & $64.3 \%$ & $35.7 \%$ & $0 \%$ & $0 \%$ & $100 \%$ \\
\hline 4 & $\begin{array}{l}\text { Is the interface in the product distribution } \\
\text { application easy to understand? }\end{array}$ & $57.1 \%$ & $42.9 \%$ & $0 \%$ & $100 \%$ & $0 \%$ \\
\hline
\end{tabular}

Based on the evaluation results, namely the average answer from the administrator and cashier was at a value of 4 (agree) or 5 (strongly agree), it can be concluded that the UCD method was successfully applied in the development of the Anyelir Cake and Bakery product distribution application system in Purwakarta. Both the functionality of the application and the appearance of the application interface have been in accordance with the needs of the user.

\section{CONCLUSION}

This mobile-base product distribution application has main feature, namely input and edit orders for user. While in the administrator section there are features of viewing incoming orders, adding products, adding users, and viewing reports. Based on the explanation in the previous section, it can be concluded that User Centered Design (UCD) method can be applied to develop a mobile-based application. The result of the application can meet the user requirements. This can be seen from the results of the evaluation carried out where almost all questions were answered with a value of 4 (agree) and 5 (totally agree).

\section{REFERENCES}

Adnan, F., Muttaqin, M. H., \& Dharmawan, T. (2018). Penerapan Metode User Centered Design Untuk Mengembangkan E-Learning Universitas Jember Berbasis Mobile. Informatics Journal, 3(3), 85-92.

Albani, L., \& Lombardi, G. (2010). User Centred Design for EASYREACH.

Frobenius, A. C. (2021). Perencanaan dan Evaluasi User Interface untuk Aplikasi Tunanetra Berbasis Mobile Menggunakan Metode User Center Design dan QUIM Evaluation. Jurnal Sistem Dan Teknologi Informasi, 9(2), 135-143.

Garret, J. J. (2011). The Elements of User Experince: User-Cetered Design for the Web and Beyond (2nd ed.). New Riders Publishing.

Intan Sandra Yatana Saputri, Fadhli, M., \& Surya, I. (2017). Penerapan Metode UCD (User Centered Design) pada E-Commerce Putri Intan Shop Berbasis Web. Jurnal Nasional Teknologi Dan Sistem Informasi, 3(2), $269-278$.

Iqbal, M., Marthasari, G. I., \& Nuryasin, I. (2020). Penerapan Metode UCD (User Centered Design) pada Perancangan Aplikasi Darurat Berbasis Android. REPOSITOR, 2(8).

Krisnoanto, A., Brata, A. H., \& Ananta, M. T. (2018). Penerapan Metode User Centered Design Pada Aplikasi E-Learning Berbasis Android (Studi Kasus: SMAN 3 Sidoarjo). Jurnal Pengembangan Teknologi Informasi Dan Ilmu Komputer, 2(12), 6495-6501.

Pranatawijaya, V. H., Widiatry, Ressa, P., Bagus, P. P., \& Anugrah, A. (2019). Penerapan Skala Likert dan Skala Dikotomi Pada Kuesioner Online. Jurnal Sains Dan Informatika, 5(2), 128-137.

Priyatna, B. (2019). PENERAPAN METODE USER CENTERED DESIGN (UCD) PADA SISTEM PEMESANAN MENU KULINER NUSANTARA BERBASIS MOBILE ANDROID. AIMS Jurnal Accounting Information System, 2(1), 1-14.

Rubin, J., \& Chisnell, D. (2008). Handbook of usability testing, second edition: how to plan, design, and conduct effective tests. Wiley Publishing.

Silvia Francesca Maria Pizzoli, Mazzocco, K., Triberti, S., Monzani, D., Raya, M. L. A., \& Pravettoni, G.

*name of corresponding author

This is an Creative Commons License This work is licensed under a

Creative Commons Attribution-NonCommercial 4.0 International

License. 


\begin{tabular}{|l|l|r|}
\hline Sin 11010 & $\begin{array}{l}\text { Sinkron : Jurnal dan Penelitian Teknik Informatika } \\
\text { Volume 7, Number 1, January 2022 } \\
\text { DOI : https://doi.org/ 10.33395/sinkron.v7i1.11218 }\end{array}$ & $\begin{array}{r}\text { e-ISSN : 2541-2019 } \\
\text { p-ISSN : 2541-044X }\end{array}$ \\
\hline
\end{tabular}

(2019). User-Centered Virtual Reality for Promoting Relaxation: An Innovative Approach. Frontiers in Psychology, 10(497), 1-8-.

Untoro, M. C. (2020). Implementation of User-Centered Design in the Online Seminar Application. JURNAL ILMIAH KOMPUTER GRAFIS, 13(1), 1-8.

Vani, T., Hidayat, R., \& Yudhistira, A. Y. F. D. (2021). Rancang Bangun Mobile Commerce di Lamandau Store Berbasis Android berdasarkan User Centered Design (UCD). JURNAL MEDIA INFORMATIKA BUDIDARMA, 5(1), 287-296. 